\title{
Mapping and Analysis Factors of Affecting Productivity Tropical Rain Forests in East Kalimantan
}

\author{
Sifriyani ${ }^{1}$, Ruslan ${ }^{2} \&$ Susanty, F. $\mathrm{H}^{3}$ \\ ${ }^{1}$ Departement of Mathematics, Faculty of Mathematics and Natural Sciences, Mulawarman University, \\ Samarinda Indonesia \\ ${ }^{2}$ Study Program of Physical and Health Education, Faculty of Teacher Training and Education, Mulawarman \\ University, Samarinda Indonesia \\ ${ }^{3}$ Research, Development and Innovation Agency, Dipterocarps Forest Ecosystem Research and Development \\ Center - Ministry of Environment and Forestry, Indonesia \\ Correspondence: Sifriyani, Department of Mathematics, Faculty of Mathematics and Natural Sciences, \\ Mulawarman University, Samarinda Indonesia. Email: sifriyani@fmipa.unmul.ac.id
}

Received: August 21, 2019

doi:10.5539/mas.v13n10p112
Accepted: September 22, $2019 \quad$ Online Published: September 24, 2019

URL: https://doi.org/10.5539/mas.v13n10p112

\begin{abstract}
Up to 2019, tropical rainforests in East Kalimantan has been experiencing very rapid degradation and continues to shrink. Therefore, it is necessary to evaluate mapping and analysis of factors affecting the productivity of tropical rain forests in East Kalimantan. The purpose of this study was to determine the factors that cause shrinkage of tropical rainforests in East Kalimantan based on spatial statistical perspectives. The data used were secondary data from the Indonesian Ministry of Forestry and the Central Bureau of Statistics. The data consisted of 10 districts/cities from East Kalimantan Province. Those data were influenced by spatial dependence and spatial heterogeneity. Nonparametric Geospatial Regression (NGR) is one of the spatial statistical methods used to overcome spatial dependence and spatial heterogeneity. The results of the study obtained was a Nonparametric Geospatial Regression modeling using the Gaussian Kernel geographical weighting function with a minimum $\mathrm{CV}$ value of 1.48 . The model had $\mathrm{R}^{2}$ values for each district/city ranging from $74.39 \%-88.65 \%$. The goodness of fit of the NGR model was shown by the value of $\mathrm{R}^{2}=0.8865$, which stated that the variables that significantly affect the preservation of tropical rainforest by $88.65 \%$ were the area of protected forests, nature reserves and nature preservation, production forests, area of each district/city, economic growth rate and regional development index.
\end{abstract}

Keywords: tropical rain forest, kernel gaussian, nonparametric geospatial regression

\section{Introduction}

According to data from the Ministry of Forestry, the forest area of East Kalimantan in 2012, around 14,981,978 hectares experienced shrinking. Hence in 2013, the forest area was around 8,563,508 hectares (BPS Kalimantan Timur, 2014). East Kalimantan has lost a forest area of 6,418,470 hectares in one year, and this value is not small and can have a negative impact if it continues. Until 2018 the forest area in East Kalimantan continues to shrink; hence, it is necessary to evaluate the handling of tropical rain forests in East Kalimantan. Tropical rainforests are degraded very quickly, many people and social organizations want to save the forest, but saving the forest will not be easy. This action requires the efforts of many parties who work together in order to preserve the forest and its wild nature; thus, it can survive for future life. The goal of sustainable development in the forestry sector is to manage forests sustainably, to fight desertification, to stop and to reverse land degradation, and to stop the loss of biodiversity.

This research is an experimental investigation of the factors that cause shrinkage of tropical rainforests in East Kalimantan based on spatial statistics perspective. The statistical method used is geospatial regression analysis named Nonparametric Geospatial Regression. The statistical method is an analysis of the relationship by including elements of geographical influence, derived from differences in environmental and geographical characteristics between the observation locations in East Kalimantan; thus each observation may have different variations.

Based on the explanation above, this research works on the development of spatial regression methods, namely Nonparametric Geospatial Regression and the statistical method applied to evaluate the handling of tropical rainforests in East Kalimantan. The stages of the analysis procedure carried out four stages are model estimation 
(Sifriyani et,al., 2017, 2018a), model suitability test (Sifriyani et,al., 2018b), simultaneous parameter significance test (Sifriyani et,al., 2019), partial parameter signification Test (Fotheringham, et, al., 2002). Based on the description above, this research works on Mapping and Analysis Factors of Affecting Productivity Tropical Rain Forests in East Kalimantan.

\section{Source Data and Methodology}

The data used are 2019 data consisting of primary data and secondary data. Secondary data comes from the Central Statistics Agency of East Kalimantan (BPS Kalimantan Timur., 2019, BPS Kalimantan Barat, 2019, BPS Kalimantan Selatan, 2019, BPS Kalimantan Utara, 2019, BPS Kalimantan Tengah, 2019, BPS Indonesia, 2018a,b,c ) and the Ministry of environment and forestry (Dinas Kehutanan, 2013, Empowered Lives Resilient Nations UNDP Indonesia, 2013). While Primary Data comes from the Research, Development and Innovation Agency, the Center for Research and Development of the Dipterocarp Forest Ecosystem. The amount of data used is 70 Observation Data from 10 Regencies / Cities in East Kalimantan with Response Variable y is the Area of Tropical Rain Forest. Predictor variables for forest governance consist of protected forest area $\left(x_{1}\right)$, nature reserve and nature conservation $\left(x_{2}\right)$ and area of each district/city $\left(x_{4}\right)$. Predictor variables for forest productivity factor consist of production forest $\left(x_{3}\right)$, economic growth rate $\left(x_{6}\right)$, regional development index $\left(x_{7}\right)$ and population density $\left(x_{5}\right)$. The method used in this research is the Geospatial Analysis of Nonparametric Geospatial Regression and Map Mapping using GIS.

\section{Results and Discussion}

\subsection{Data Exploration}

Figure 1 shows the distribution map of tropical rainforests in each district/city in Kalimantan. District/city that had the largest area of tropical rainforest was West Kutai District with an area of 2,500,103 hectares. Most of the area around West Kutai had a fairly large forest area, and most of the area far from West Kutai had a fairly small forest area.

The relationship between independent variables can be seen using Pearson correlation. Variables $x_{1}, x_{2}, x_{3}$, $x_{4}, x_{5}, x_{6}$ and $x_{7}$ had a relatively strong positive relationship with $\mathrm{y}$, while the variables among variables $x_{1}, x_{2}, x_{3}, x_{4}, x_{5}, x_{6}$ and $x_{7}$ had a weak relationship. All independent variables were used in this study because the relationship between independent and response variables was high; meanwhile, the relationships between independent variables was low; thus, there is no indication of multicollinearity.

Conditions in a district/city depend on the condition of the surrounding district/city, and the geographical, economic and socio-cultural conditions in a district/city are different from the conditions in other districts/cities. This condition shows the existence of spatial effects. The spatial effects that occur between regions are divided into two, namely spatial dependence and spatial heterogeinity. Spatial dependence can be seen using Moran's Index and the presence of spatial heterogeinity can be seen using Breush-Pagan test. Moran's Index value was 0.284 , with P-value of 0.0068 . A very small P-Value caused $\mathrm{H}_{0}$ to reject, which means there was spatial dependence. The presence of spatial dependence indicated that the area of tropical rain forest in one district/city depends on other districts/cities in Kalimantan.

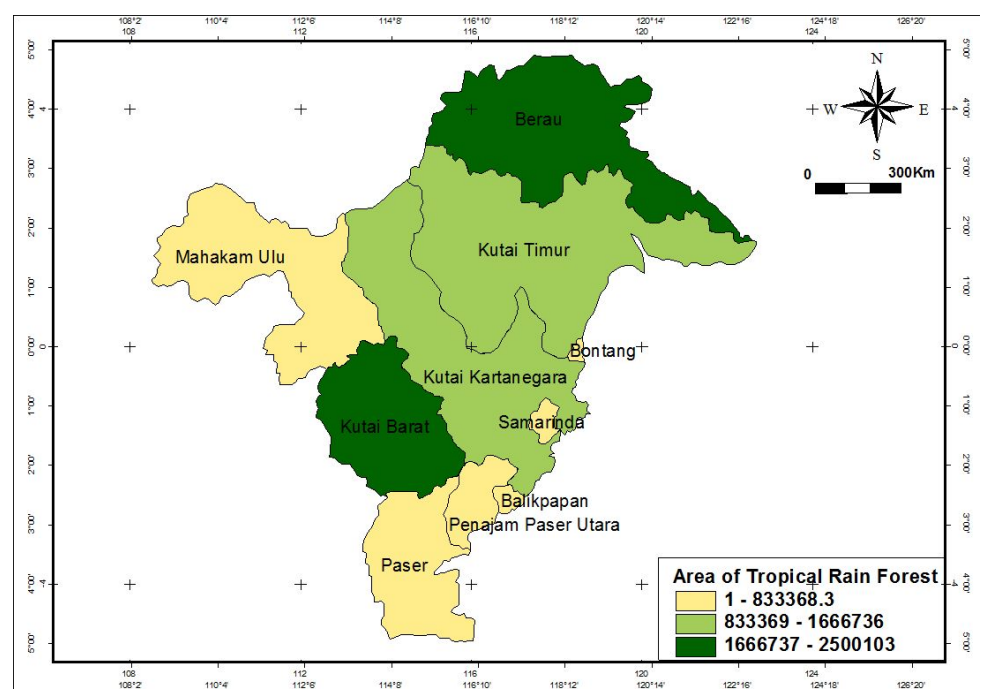

Figure 1. Map of Spatial Heterogeinity in the Area of Tropical Rain Forests

Pagan Breusch Test produced a value of 13.1288 with a P-value of 0.04925 . A small P-value caused $\mathrm{H}_{0}$ to reject, which means there was spatial heterogeinity. The presence of spatial heterogeinity indicated that there 
were differences in independent variables related to the area of tropical rainforests among districts/cities in East Kalimantan. The existence of spatial dependence and spatial heterogeinity can be overcome by Nonparametric Geospatial Regression.

\subsection{Nonparametric Geospatial Regression Modeling}

Nonparametric Geospatial Regression (NGR) produces a regression coefficient estimator that is local, which means that each district/city has a different regression model. The weighting matrix in each district/city was determined in advance to obtain the NGR model for each district/city. The weighting matrix used was the Gaussian and Bisquare kernel functions. In this study, the value of bandwidth was needed to obtain the weighting matrix. The optimum bandwidth value was obtained from the iteration results that produced the minimum Cross-Validation (CV) value. The results of the study for two geographical weighting functions in Table 1 yield the optimum bandwidth value given to the Gaussian kernel function with a bandwidth value of 40 and CV 1,477992.

The goodness of fit of the NGR model was shown by the coefficient of determination $\left(\mathrm{R}^{2}\right)$. The $\mathrm{R}^{2}$ value of the overall NGR model is 0.8865 , which means that $88.65 \%$ of the heterogeinity of tropical rainforests area in a district/city can be explained by the heterogeinity of $x_{1}, x_{2}, x_{3}, x_{4}, x_{5}, x_{6}$ and $x_{7}$. The $\mathrm{R}^{2}$ value of NGR models for each district/city range from $74.39 \%-88.65 \%$.

Table 1. Optimum Bandwidth Value

\begin{tabular}{ccc}
\hline Weighted Function & Optimal Bandwidth & Cross Validation \\
\hline Gaussian Kernel & 40 & $1,477992 \mathrm{e}+13$ \\
Bisquare Kernel & 53 & $1,629769 \mathrm{e}+13$ \\
\hline
\end{tabular}

Table 2. Geographical Weighting Matrix of the Area of Tropical Rain Forests in East Kalimantan

\begin{tabular}{cccccccc}
\hline District/City & $w_{1}$ & $w_{2}$ & $w_{3}$ & $w_{4}$ & $w_{5}$ & $w_{6}$ & $w_{7}$ \\
\hline $\begin{array}{c}\text { Paser District } \\
\text { West Kutai }\end{array}$ & 0,214833 & 0,292557 & 0,204851 & 0,141511 & 0,223069 & 0,752463 & 0,913865 \\
District & 0,458749 & 0,53239 & 0,435351 & 0,312679 & 0,434981 & 0,500149 & 0,621633 \\
Kutai Kartanegara & 0,438346 & 0,571048 & 0,431368 & 0,34207 & 0,476299 & 0,436678 & 0,650517 \\
East Kutai District & 0,595175 & 0,757455 & 0,599335 & 0,523919 & 0,671543 & 0,254862 & 0,439412 \\
Berau District & 0,868602 & 0,97482 & 0,880228 & 0,824954 & 0,932494 & 0,111564 & 0,208135 \\
North Penajam & & & & & & & \\
Paser Distric & 0,297795 & 0,404608 & 0,28935 & 0,215157 & 0,321596 & 0,599812 & 0,816451 \\
Mahakam Ulu & & & & & & & \\
District & 0,566945 & 0,600246 & 0,533156 & 0,382059 & 0,503341 & 0,378982 & 0,459395 \\
Balikpapan City & 0,302306 & 0,412924 & 0,294638 & 0,22129 & 0,329512 & 0,582601 & 0,806457 \\
Samarinda City & 0,42667 & 0,564194 & 0,42154 & 0,337617 & 0,471095 & 0,42899 & 0,651295 \\
Bontang City & 0,519021 & 0,674217 & 0,518848 & 0,437693 & 0,582489 & 0,323187 & 0,529722 \\
\hline
\end{tabular}


Table 3. Geographical Weighting Matrix of the Area of Tropical Rain Forests in East Kalimantan

\begin{tabular}{ccccccccc}
\hline District/City & $\beta_{0}$ & $\beta_{1}$ & $\beta_{2}$ & $\beta_{3}$ & $\beta_{4}$ & $\beta_{5}$ & $\beta_{6}$ & $\beta_{7}$ \\
\hline $\begin{array}{c}\text { Paser District } \\
\text { West Kutai }\end{array}$ & -1351088 & -0.566 & 1.149 & -1.212 & 116.143 & 6.359 & -83064.3 & 20025.38 \\
$\quad \begin{array}{c}\text { District } \\
\text { Kutai }\end{array}$ & -1404010 & -0.597 & 1.158 & -1.233 & 117.984 & 6.174 & -84930.96 & 20840.59 \\
$\quad \begin{array}{c}\text { Kartanegara } \\
\text { East Kutai }\end{array}$ & -1478407 & -0.424 & 1.231 & -1.078 & 106.946 & 4.179 & -85719.68 & 20898.22 \\
$\quad$ District & -1539613 & -0.359 & 1.256 & -1.030 & 103.345 & 3.523 & -86691.48 & 21023.37 \\
Berau District & -1607951 & -0.336 & 1.271 & -1.013 & 102.079 & 3.134 & -87715.89 & 21319.35 \\
$\begin{array}{c}\text { North Penajam } \\
\text { Paser Distric }\end{array}$ & -1423472 & -0.472 & 1.203 & -1.122 & 109.947 & 4.937 & -84682.42 & 20547.81 \\
Mahakam Ulu & -1403987 & -0.648 & 1.138 & -1.294 & 122.081 & 6.962 & -86256.93 & 21018 \\
$\quad$ District & & & & & & & & \\
Balikpapan City & -1430907 & -0.459 & 1.208 & -1.112 & 109.194 & 4.796 & -84830.51 & 20571.57 \\
Samarinda City & -1482148 & -0.412 & 1.238 & -1.070 & 106.274 & 4.101 & -85771.06 & 20859.59 \\
Bontang City & -1516508 & -0.378 & 1.248 & -1.044 & 104.362 & 3.724 & -86334.81 & 20962.26 \\
\hline
\end{tabular}

The weighting matrix in each district/city was different and was used to estimate the regression coefficient estimator on variables $x_{1}, x_{2}, x_{3}, x_{4}, x_{5}, x_{6}$ and $x_{7}$. Table 2 shows the geographical weighting results. Based on geographical weighting in Table 2, an NGR parameter estimator was generated for each district/city. The NGR parameter estimator is shown in Table 3. Each district/city in East Kalimantan had a different NGR model. The NGR model for each Regency/City is shown in Table 4.

Table 4. NGR models in 10 districts / cities of East Kalimantan

\begin{tabular}{|c|c|}
\hline District/City & Nonparametric Geospasial Regression Model \\
\hline Paser District & $\begin{array}{c}\hat{y}=-1351088-0.566 x_{1}+1.149 x_{2}-1.212 x_{3}+116.143 x_{4}+6.359 x_{5} \\
-83064.3 x_{6}+20025.38 x_{7}\end{array}$ \\
\hline West Kutai District & 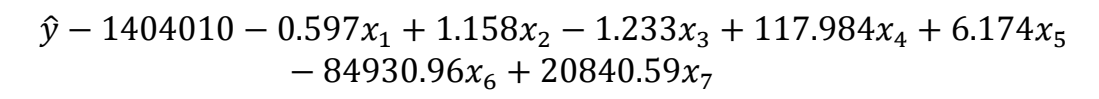 \\
\hline Kutai Kartanegara & $\begin{array}{c}\hat{y}=-1478407-0.424 x_{1}+1.231 x_{2}-1.078 x_{3}+106.946 x_{4}+4.179 x_{5} \\
-85719.68 x_{6}+20898.22 x_{7}\end{array}$ \\
\hline East Kutai District & $\begin{array}{c}\hat{y}=-1539613-0.359 x_{1}+1.256 x_{2}-1.030 x_{3}+103.345 x_{4}+3.523 x_{5} \\
-86691.48 x_{6}+21023.37 x_{7}\end{array}$ \\
\hline Berau District & $\begin{array}{c}\hat{y}=-1607951-0.3369 x_{1}+1.271 x_{2}-1.013 x_{3}+102.079 x_{4}+3.134 x_{5} \\
-87715.89 x_{6}+21319.35 x_{7}\end{array}$ \\
\hline $\begin{array}{l}\text { North Penajam } \\
\text { Paser Distric }\end{array}$ & $\begin{array}{c}\hat{y}=-1423472-0.472 x_{1}+1.203 x_{2}-1.122 x_{3}+109.947 x_{4}+4.937 x_{5} \\
-84682.42 x_{6}+20547.81 x_{7}\end{array}$ \\
\hline $\begin{array}{l}\text { Mahakam Ulu } \\
\text { District }\end{array}$ & $\begin{array}{c}\hat{y}=-1403987-0.648 x_{1}+1.138 x_{2}-1.294 x_{3}+122.081 x_{4}+6.962 x_{5} \\
-86256.93 x_{6}+21018 x_{7}\end{array}$ \\
\hline Balikpapan City & $\begin{array}{c}\hat{y}=-1430907-0.459 x_{1}+1.208 x_{2}-1.112 x_{3}+109.194 x_{4}+4.796 x_{5} \\
-84830.51 x_{6}+20571.57 x_{7}\end{array}$ \\
\hline Samarinda City & $\begin{array}{c}\hat{y}=-1482148-0.412 x_{1}+1.238 x_{2}-1.070 x_{3}+106.274 x_{4}+4.101 x_{5} \\
-85771.06 x_{6}+20859.59 x_{7}\end{array}$ \\
\hline Bontang City & $\begin{array}{c}\hat{y}=-1516508-0.378 x_{1}+1.248 x_{2}-1.044 x_{3}+104.362 x_{4}+3.724 x_{5} \\
-86334.81 x_{6}+20962.26 x_{7}\end{array}$ \\
\hline
\end{tabular}




\subsection{Mapping and Analysis of Factors Affecting Productivity of Tropical Rain Forests in East Kalimantan}

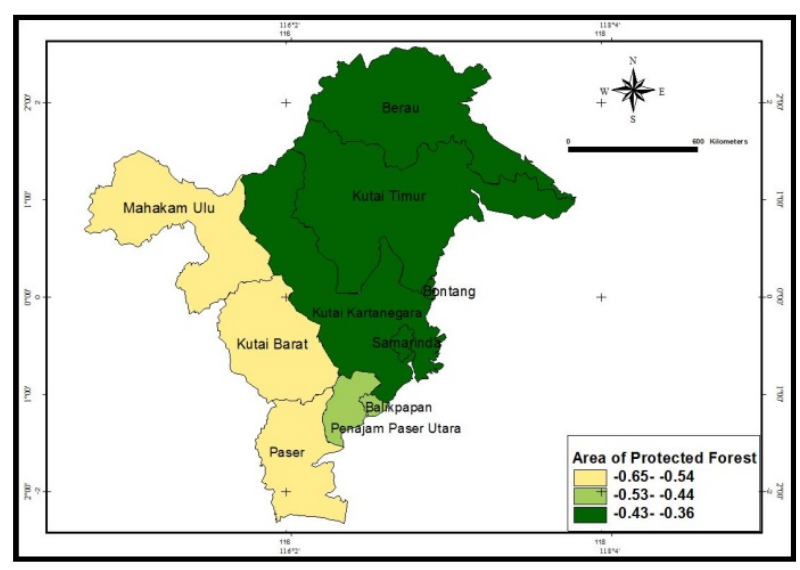

Figure 2. Map of Spatial Heterogeinity of Regression Coefficient Estimator $x_{1}$

Figure 2 describes the mapping based on the size of the contribution effect of the protected forest area $\left(x_{1}\right)$ to the preservation of tropical rainforests in each district/city of East Kalimantan. The effect had a negative contribution to the preservation of tropical rainforests, which means that the greater protected forests area would have an impact on the decreasing area of tropical rain forests in East Kalimantan. Figure 2 also shows that the district that had the most significant regression coefficient estimator value for the variable $x_{1}$ was Berau District. The contribution given was -0.336 . This result means that if the protected forest became wider by 0.336 $\mathrm{Ha}$, it would have a $1 \mathrm{Ha}$ decrease in the area of tropical rainforest. Most of the area around Berau District had a quite large regression coefficient estimator compared to remote areas which were East Kutai, Kutai Kartanegara, Bontang, and Samarinda City. West Kutai District had the largest area of tropical rainforest compared to other districts/cities in East Kalimantan, but it had a smaller $x_{1}$ estimator value.

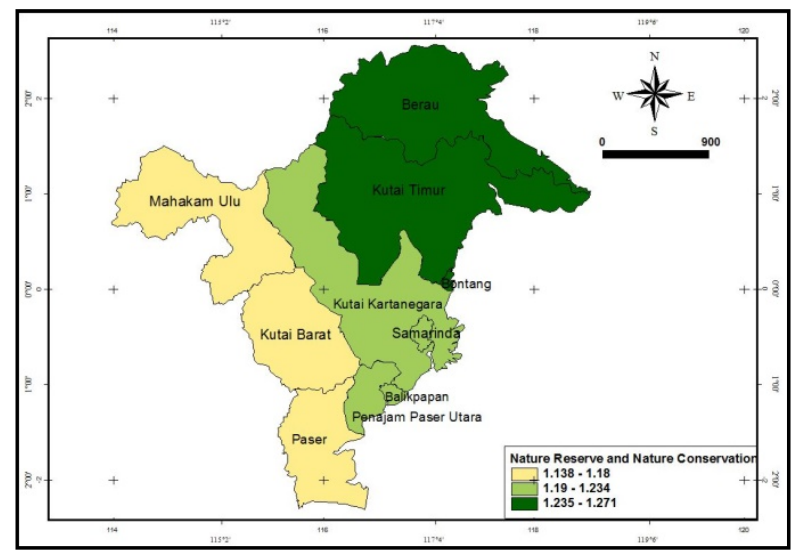

Figure 3. Map of Spatial Heterogeinity of Regression Coefficient Estimator $x_{2}$

Figure 3 describes the mapping based on the size of the contribution effect of the nature reserve and nature conservation $\left(x_{2}\right)$ to the preservation of tropical rainforests in each district/city of East Kalimantan. The effect had a positive contribution to the preservation of tropical rainforests, which means that the greater nature reserve and nature conservation would have an impact on the increasing conservation of tropical rain forests area in East Kalimantan. Figure 3 also shows that the district that had the most significant regression coefficient estimator value for the variable $x_{2}$ was Berau District. The contribution given was 1.27. This result means that if nature reserves and nature preservation were as wide as $1.27 \mathrm{ha}$, it would have an impact on an increase of 1 ha in the area of tropical rainforest. Most of the area around Berau District had a quite large regression coefficient estimator compared to remote areas which were East Kutai, and Bontang. Mahakam Ulu District had the smallest area of tropical rainforest compared to other districts/cities in East Kalimantan. A contribution of 1,137 ha will increase 1 ha of tropical rainforest in the Mahakam Ulu. 


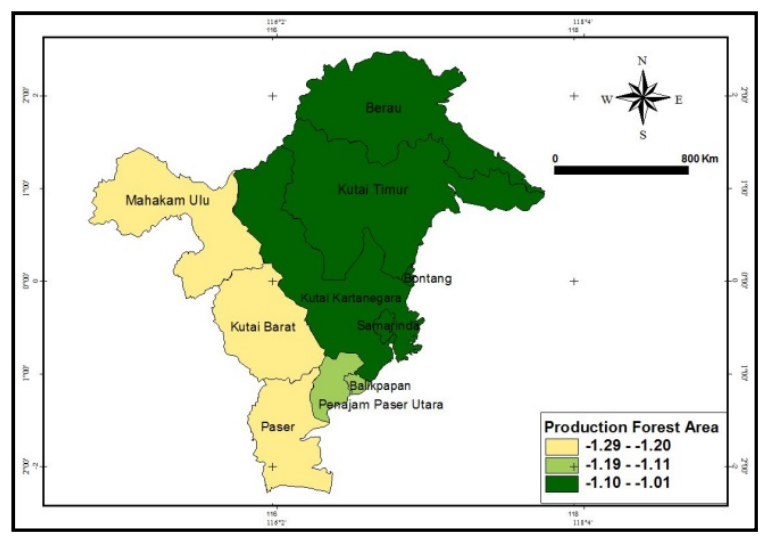

Figure 4. Map of Spatial Heterogeinity of Regression Coefficient Estimator $x_{3}$

Figure 4 describes the mapping based on the size of the contribution effect of the production forest area $\left(x_{3}\right)$ to the preservation of tropical rainforests in each district/city of East Kalimantan. The effect had a negative contribution to the preservation of tropical rainforests, which means that the greater production forest area would have an impact on the decreasing conservation of tropical rain forests area in East Kalimantan. Figure 4 also shows that the districts that had the largest and smallest regression coefficient estimator value for the variable $x_{3}$ respectively were Berau District and Mahakam Ulu District. Most of the area around Berau District had a quite large regression coefficient estimator compared to remote areas which were East Kutai, Bontang, Kutai Kartanegara, and Samarinda; they were labeled by green color. Mahakam Ulu District had the smallest $x_{3}$ estimator compared to other districts/cities in East Kalimantan. The contribution of -1.293 Ha would reduce $1 \mathrm{Ha}$ of tropical rainforest in the Mahakam Ulu.

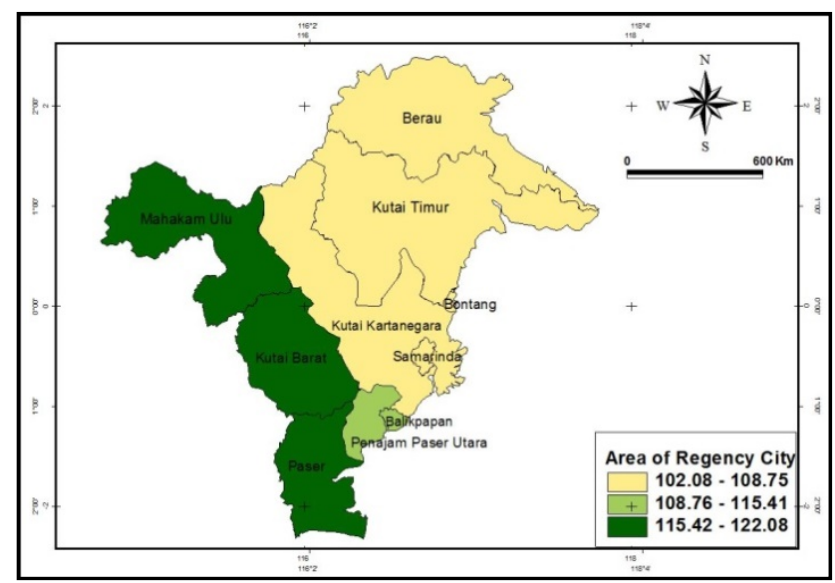

Figure 5. Map of Spatial Heterogeinity of Regression Coefficient Estimator $x_{4}$

Figure 5 shows the effect of the area of each district/city on the area of tropical rainforest. The effect gave a positive contribution to the conservation of tropical rainforests in East Kalimantan. Some regions that had more enormous contributions are shown by green-colored areas, namely Mahakam Ulu, West Kutai and Paser District whereas the areas which had a small effect are shown by yellow-colored areas, namely Berau District, East Kutai, Bontang, Kutai Kartanegara, and Samarinda City. 


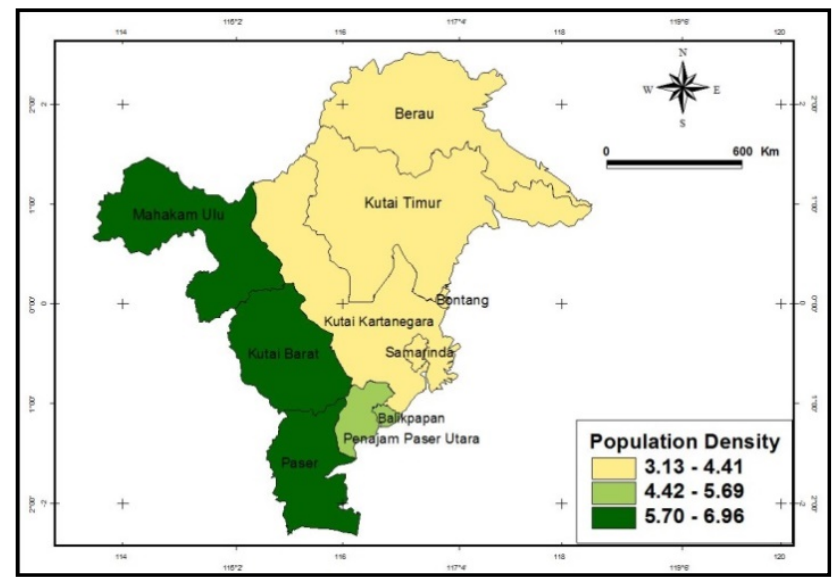

Figure 6. Map of Spatial Heterogeinity of Regression Coefficient Estimator $x_{5}$

Figure 6 shows the effect of population density on the area of tropical rainforests. The effect gave a positive contribution to the preservation of tropical rainforests in East Kalimantan. Some areas that had more enormous contribution are shown by green-colored areas, namely Mahakam Ulu District, West Kutai and Paser. Meanwhile, the areas that had a small effect are shown by yellow-colored areas, namely Berau District, East Kutai, Bontang, Kutai Kartanegara, and Samarinda City.

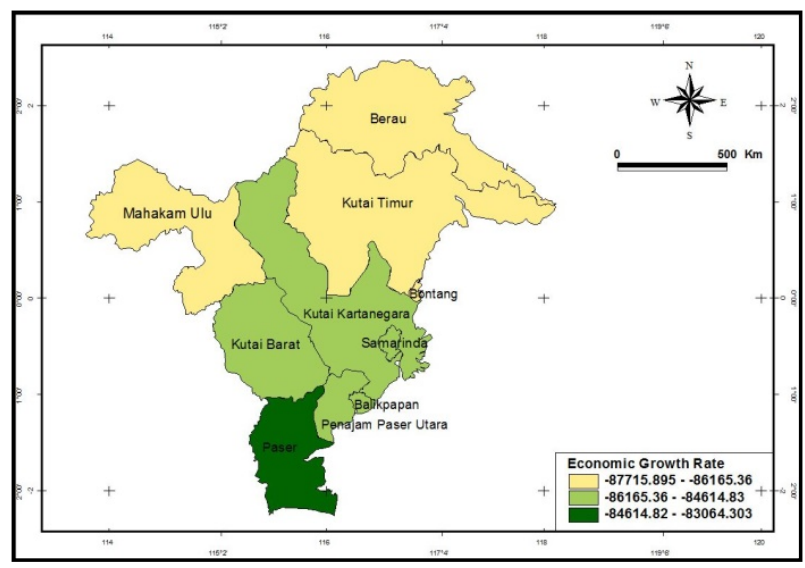

Figure 7. Map of Spatial Heterogeinity of Regression Coefficient Estimator $x_{6}$

Figure 7 shows the effect of the economic growth rate on the area of tropical rainforests. The effect negatively contributed to the preservation of tropical rainforests in East Kalimantan. Some areas that had a more enormous contribution are shown by green-colored areas, namely Paser Regency. Meanwhile, the areas that had a small effect is shown by yellow-colored areas, namely Mahakam Ulu, Berau, East Kutai, and Bontang District.

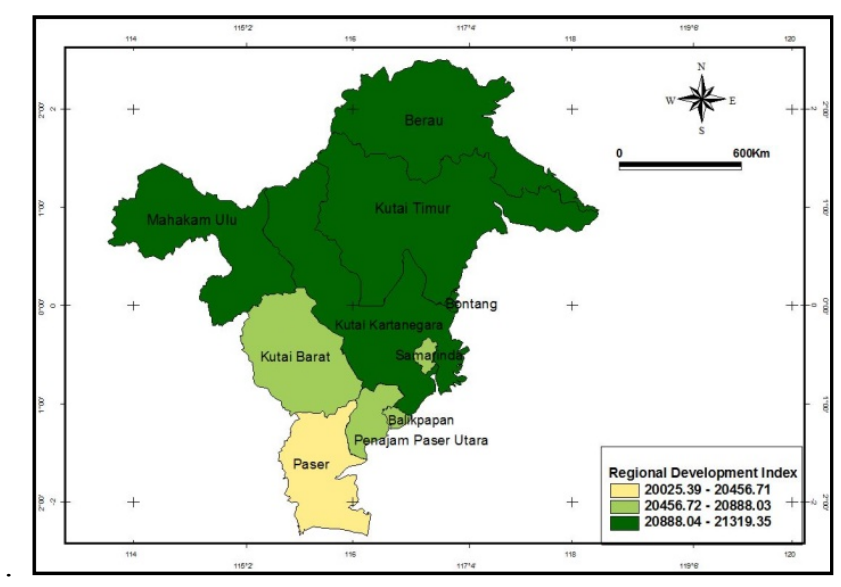

Figure 8. Map of Spatial Heterogeinity of Regression Coefficient Estimator $x_{7}$ 
Figure 8 shows the effect of the regional development index on the area of tropical rainforests. The effect gave a positive contribution to the preservation of tropical rainforests in East Kalimantan. The greater regional development index would be able to further preserve tropical rainforests in East Kalimantan. Some regions that had a more enormous contribution are shown by green-colored areas, namely Berau District, East Kutai, Bontang, Kutai Kartanegara, and Mahakam Ulu. Meanwhile, the area that had a small effect is shown by the yellow-colored area, namely Paser District.

\subsection{Test for Significance of NGR Parameters}

The significance test of NGR parameters aims to determine the factors that have a significant effect on the preservation of tropical rainforests in each district/city in East Kalimantan. Statistics tests for partial testing of the NGR model used the following formula:

$$
t=\frac{\hat{\tilde{\eta}}\left(u_{i}, v_{i}\right)}{S E\left(\hat{\tilde{\eta}}\left(u_{i}, v_{i}\right)\right)},
$$

which $S E\left(\hat{\tilde{\eta}}\left(u_{i}, v_{i}\right)\right)=\sqrt{g_{k k}}$ and $g_{k k} \quad$ is a $k+1$-th diagonal element diagonal from matrix $\left(Q^{\mathrm{T}} \mathrm{W}\left(u_{i}, v_{i}\right) Q\right)^{-1} \hat{\sigma}^{2}\left(u_{i}, v_{i}\right)$. The statistics test (1) followed the $t$ distribution with a degree of freedom $(n-1)$ and level significance $\alpha$, therefore the decision taken is reject $\mathrm{H}_{0}$ if $|t|>t_{\left(\frac{\alpha}{2},(n-1)\right)}$.

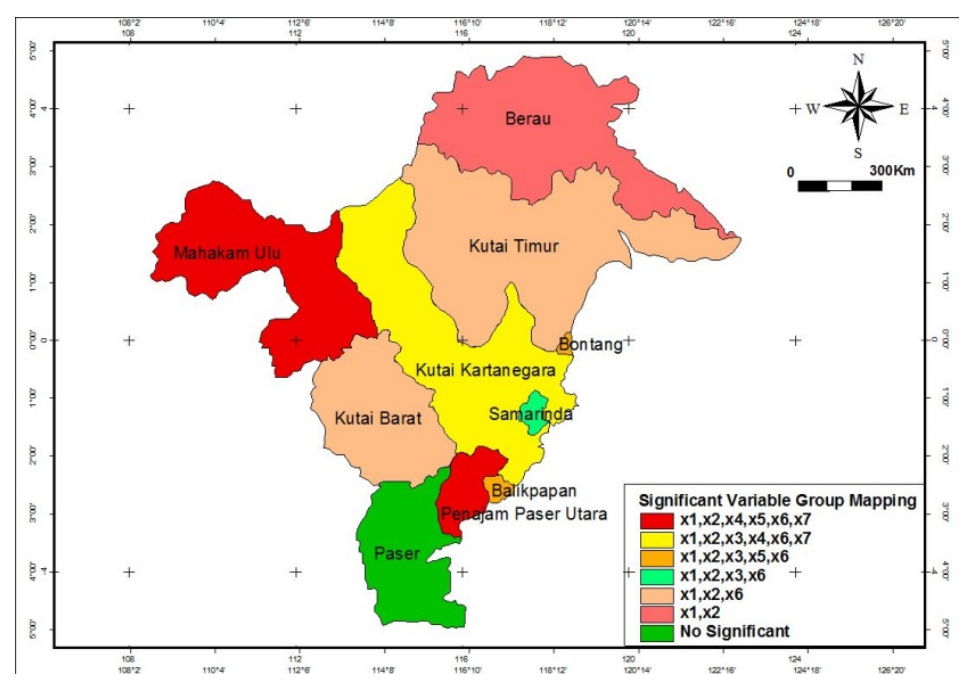

Figure 9. Map of Spatial Heterogeinity of Significant Variables Grouping

The significance test results of the equation (1) are given in Table 5. Mapping the spatial heterogeinity results of the significance tests is given in Figure 9 and described in Table 6.

Table 5. Test results for Partial Parameter Significance

\begin{tabular}{|c|c|c|c|c|c|c|c|}
\hline District/City & $\operatorname{Sig} \beta_{1}$ & $\operatorname{Sig} \beta_{2}$ & $\mathrm{Sig} \beta_{3}$ & Sig $\beta_{4}$ & $\operatorname{Sig} \beta_{5}$ & $\operatorname{Sig} \beta_{6}$ & $\operatorname{Sig} \beta_{7}$ \\
\hline Paser District & 0.158 & 0.158 & 0.158 & 0.158 & 0.126 & 533,88 & 0.735 \\
\hline $\begin{array}{l}\text { West Kutai } \\
\text { District }\end{array}$ & $0.006^{*}$ & 0.021 & 0.993 & 0.897 & 0.671 & 0.008 & 0.892 \\
\hline Kutai Kartanegara & $0,00^{*}$ & 0,00 & 0.00888 & 0.00047 & 263,12 & 0,00 & 0.000248 \\
\hline East Kutai District & $0,00^{*}$ & 0,00 & 0.990 & 0.276 & 0.113 & 0,00 & 0.237 \\
\hline Berau District & $0.055^{*}$ & 0.014 & 0.997 & 0.913 & 0.811 & 386,08 & 0.901 \\
\hline $\begin{array}{l}\text { North Penajam } \\
\text { Paser Distric }\end{array}$ & $0,00^{*}$ & 0,00 & 0.954 & 0.0082 & 0.03 & 0,00 & 0.066 \\
\hline $\begin{array}{c}\text { Mahakam Ulu } \\
\text { District }\end{array}$ & $0,00^{*}$ & 0,00 & 461 & 0,00 & 0,00 & 0,00 & 0,00 \\
\hline Balikpapan City & $0,00^{*}$ & 0,00 & 0.00674 & 18,61 & 0,011 & 0,00 & 4,86 \\
\hline Samarinda City & 0,00 & 0,00 & 0.00879 & 530,42 & 535,62 & 0,00 & 239,52 \\
\hline Bontang City & 0,00 & 0,00 & 0.0080 & 1262,88 & 0,04 & 0,00 & 258,30 \\
\hline
\end{tabular}


Factors affecting the preservation of tropical rainforests in East Kalimantan were the area of protected forest $\left(x_{1}\right)$, nature reserve and nature conservation $\left(x_{2}\right)$, production forest $\left(x_{3}\right)$, area of each district/city $\left(x_{4}\right)$, population density $\left(x_{5}\right)$, economic growth rate $\left(x_{6}\right)$ and regional development index $\left(x_{7}\right)$. Table 6 shows the results of district/city groupings based on significant variables.

Table 6. District/City Grouping Based on Significant Variables

\begin{tabular}{lcc}
\hline \multicolumn{1}{c}{ District/City } & $\begin{array}{c}\text { Factors Affecting Tropical Rain } \\
\text { Forests in each District/City }\end{array}$ & Group \\
\hline $\begin{array}{l}\text { North Penajam Paser } \\
\text { District }\end{array}$ & $\begin{array}{c}\text { The area of protected forest }\left(\mathrm{x}_{1}\right), \\
\text { nature reserve and nature } \\
\text { conservation }\left(\mathrm{x}_{2}\right) \text {, area of each } \\
\text { district / city }\left(\mathrm{x}_{4}\right) \text {, population } \\
\text { density }\left(\mathrm{x}_{5}\right), \text { economic growth rate } \\
\left(\mathrm{x}_{6}\right) \text { and regional development } \\
\text { Mahakam Ulu }\left(\mathrm{x}_{7}\right) .\end{array}$ & 1 \\
District & $x_{1}, x_{2}, x_{3}, x_{4}, x_{6}, x_{7}$ & 2 \\
$\begin{array}{l}\text { Kutai Kartanegara } \\
\text { Balikpapan City }\end{array}$ & $x_{1}, x_{2}, x_{3}, x_{5}, x_{6}$ & 3 \\
$\begin{array}{l}\text { Bontang City } \\
\text { Samarinda City }\end{array}$ & $x_{1}, x_{2}, x_{3}, x_{6}$ & 4 \\
West Kutai District & $x_{1}, x_{2}, x_{6}$ & 5 \\
East Kutai District & $x_{1}, x_{2}$ & 6 \\
Berau District & No Significant Variables & 7 \\
Paser District & & \\
\hline
\end{tabular}

\section{Conclusion}

The NGR geospatial regression model using Gaussian kernel weighting produced an $\mathrm{R}^{2}$ value of 88.65 . This value explained that $88.65 \%$ of the variable area of protected forest, nature reserve and nature conservation, production forest, area of each district/city, population density, economic growth rate, and regional development index affected the preservation of tropical rainforests in East Kalimantan. The partial test results of the regression estimator classified districts/cities into seven groups based on the independent variables associated with tropical rainforests in East Kalimantan.

\section{Acknowledgment}

The author acknowledges The Research Center of Medicine and cosmetics from Tropical Rainforest Resources for generously supporting this project.

\section{References}

BPS Kalimantan Timur. (2014). Provinsi Kalimantan Timur dalam Angka. Badan Pusat Statistika. Provinsi Kalimantan Timur.

BPS Kalimantan Timur. (2019). Provinsi Kalimantan Timur dalam Angka. Badan Pusat Statistika. Provinsi Kalimantan Timur.

BPS Kalimantan Barat. (2019). Provinsi Kalimantan Barat dalam Angka. Badan Pusat Statistika. Provinsi Kalimantan Barat.

BPS Kalimantan Selatan. (2019). Provinsi Kalimantan Selatan dalam Angka. Badan Pusat Statistika Provinsi Kalimantan Selatan.

BPS Kalimantan Utara. (2019). Provinsi Kalimantan Utara dalam Angka. Badan Pusat Statistika. Provinsi Kalimantan Utara.

BPS Kalimantan Tengah. (2019). Provinsi Kalimantan Tengah dalam Angka. Badan Pusat Statistika. Provinsi Kalimantan Tengah.

BPS Indonesia. (2018a). Statistics of Forestry Production 2017. BPS. Statistics Indonesia.

BPS Indonesia. (2018b). Statistical Yearbook of Indonesia 2017. BPS. Statistics Indonesia.

BPS Indonesia. (2018c). Direktori Perusahaan Kehutanan 2017. BPS. Statistics Indonesia. 
Dinas Kehutanan. (2013). Indeks Kelola Hutan dan Lahan Daerah. Kinerja Daerah Dalam Pengelolaan Hutan dan Lahan di Indonesia.

Empowered Lives Resilient Nations UNDP Indonesia. (2013). Indeks Tata Kelola Hutan, Lahan dan REDD+ 2012 di Indonesia. Dinas Kehutanan.

Fotheringham, A.S, Brundson, C and Charlton, M. (2002). Geographically Weighted Regression: The Analysis of Spatially Varying Relationships, John Wiley \& Sons Ltd, England.

Sifriyani, Haryatmi, I.N Budiantara, and Gunardi. (2017). Geographically Weighted Regression with Spline Approach. Far East Journal of Mathematical Sciences, 101(6), 1183-1196.

Sifriyani, S. H. Kartiko, I. N. Budiantara and Gunardi. (2018a). Development Of Nonparametric Geographically Weighted Regression Using Truncated Spline Approach. Songklanakarin Journal of Science and Technology, 40(4), 909-920.

Sifriyani, I.N. Budiantara, S.H. Kartiko and Gunardi. (2018b). A New Method of Hypothesis Test for Truncated Spline Nonparametric Regression Influenced by Spatial Heterogeneity and Application. Abstract and Applied Analysis. 2018. https://doi.org/10.1155/2018/9769150

Sifriyani. (2018c). Multivariable Nonparametric Regression Truncated Spline in The Geographically Weighted Regression Models. Unpublished Ph.D. Dissertation. Universitas Gadjah Mada. Dept of Mathematics.

Sifriyani, Budiantara, I. N., Kartiko, S.H. \& Gunardi. (2019). Evaluation of Factors Affecting Increased Unemployment in East Java Using NGWR-TS Method. International Journal Of Sciences: Basic and Applied Research, 49(1), 123-142.

Sifriyani, (2019). Simultaneous Hypothesis Testing of Multivariable Nonparametric Spline Regression in the GWR Model. International Journal of Statistics and Probability, 8(4).

\section{Copyrights}

Copyright for this article is retained by the author(s), with first publication rights granted to the journal.

This is an open-access article distributed under the terms and conditions of the Creative Commons Attribution license (http://creativecommons.org/licenses/by/4.0/). 